\title{
Mechanism of Galanin's inhibitory action on pancreatic enzyme secretion: modulation of cholinergic transmission - studies in vivo and in vitro
}

\author{
K-H Herzig, G Brunke, I Schön, M Schäffer, U R Fölsch
}

\begin{abstract}
This study examined the inhibitory mechanism of galanin, a 29 amino acid polypeptide on pancreatic enzyme secretion in anaesthetised rats, isolated pancreatic acini, and lobules. Urethane anaesthetised rats with pancreatic fistulas pretreated with 3-0-methylglucopyranose $(500 \mathrm{mg} / \mathrm{kg} / \mathrm{h})$ were stimulated with an intravenous bolus of 2-deoxyglucose (2-DG) $(75 \mathrm{mg} / \mathrm{kg})$. Maximal amylase secretion was mean (SEM) 274 (19)\% of basal secretion. Atropine $(150 \mu \mathrm{g} / \mathrm{kg} / \mathrm{h})$ and galanin (10 nmol/kg/h) almost completely inhibited 2-DG stimulated amylase secretion suggesting an inhibition of cholinergic transmission. To further test this possibility this study investigated the effect of galanin on carbachol and cholecystokinin stimulated amylase release from isolated pancreatic acini. Galanin did not suppress carbachol or cholecystokinin stimulated amylase release, indicating that galanin inhibits exocrine secretion by indirect mechanisms. The cholinergic pathway was assessed by using pancreatic lobules containing intrapancreatic neurons. Veratridine, a sodium channel activator, dose dependently stimulated amylase release. Veratridine $(100 \mu M)$ stimulated amylase release by $411(10) \%$ of basal secretion. Atropine $(1 \mu M)$ or tetrodotoxin $(1 \mu \mathrm{M})$ almost completely blocked veratridine stimulated amylase release. Galanin $(1 \mu M)$ significantly inhibited veratridine stimulated amylase release with a maximal inhibition of $50 \%(p<0.05)$. In addition, when lobules were incubated with $\left[{ }^{3} \mathbf{H}\right]-$ choline, galanin significantly $(p<0.05)$ inhibited veratridine stimulated release of newly synthesised $\left[{ }^{3} \mathrm{H}\right]$-acetylcholine. Thus galanin inhibits pancreatic secretion by inhibiting cholinergic transmission. These studies show that galanin inhibits rat pancreatic enzyme secretion by an indirect mechanism by reducing cholinergic transmission.

(Gut 1993; 34: 1616-1621)
\end{abstract}

Galanin, a 29 amino acid peptide, was first isolated from porcine intestinal mucosa by Tatemoto et al using a method that detects its C-terminal amide structure.' The name was derived from its $\mathrm{N}$-terminal amino acid glycine and the $\mathrm{C}$-terminal amino acid alanine. Galanin is widely distributed in the neurons of the central nervous system and the gut and coexists with norepinephrine, serotonin, $\gamma$-amino butyric acid, vasopressin, cholecystokinin (CCK) and acetylcholine. ${ }^{2-5}$ The localisation and the coexistence with these neurotransmitters strongly suggests that galanin plays an important part in the modulation of neural transmission. In the pancreas galanin immunoreactive nerve fibres have been detected in several species, only the intrapancreatic abundance and distribution varies slightly among them. ${ }^{6-9}$ In the rat galanin immunoreactive nerve fibres are located around blood vessels and scattered in the exocrine pancreatic parenchyma, occasionally in the islets. ${ }^{8}$ In the dog pancreas on the other hand, galanin immunoreactive nerves are most abundant in the islets. ${ }^{6}$ Galanin immunoreactivity has not been detected in the intrapancreatic neurons of the dog, therefore Dunning et al suggested an extrinsic origin of the galanin immunoreactive nerves. In contrast with dogs, in the human pancreas galanin immunoreactive nerves are mainly distributed in the exocrine tissue including intrapancreatic ganglia. ${ }^{9}$ According to their results Shimosegawa et al suggested an intrinsic origin of galanin immunoreactivity and speculated that in the human pancreas galanin is a likely neurotransmitter in the parasympathetic postganglionic nerve system.

Mixed pancreatic nerve stimulation releases galanin into the venous effluent of dogs inhibiting insulin and somatostatin secretion and modestly stimulating glucagon output. ${ }^{10}$ In addition, galanin has been shown to inhibit the secretion of other gastrointestinal hormones, gut motility, and exocrine pancreatic secretion. ${ }^{3112}$ The mechanism, however, through which galanin acts to inhibit exocrine pancreatic secretion is unclear. In the brain and the myenteric plexus galanin has been shown to inhibit cholinergic transmission. ${ }^{13-15}$ On the other hand, galanin weakly inhibited amylase release from isolated rat pancreatic acini suggesting a direct effect on the acini. ${ }^{16}$

Therefore, in this study we investigated the hypothesis that galanin inhibits pancreatic enzyme secretion by presynaptic modulation of acetylcholine release. To test this hypothesis we examined the effect of galanin (a) on 2-deoxyglucose (2-DG) stimulated amylase release in anaesthetised rats, (b) on CCK8 and carbachol stimulated amylase release from isolated pancreatic acini devoid of neural elements, (c) on the sodium channel activator veratridine stimulated amylase release from pancreatic lobules contain- 
ing neural elements, and (d) on veratridine stimulated acetylcholine release.

\section{Materials and methods}

\section{MATERIALS}

The following substances were purchased: trypsin (type II-S), soybean trypsin inhibitor (SBTI) (type I-S), 2-deoxyglucose, 3-0-methylglucopyranose, taurocholate, veratridine, tetrodotoxin, physostigmine, hemicholinium, atropine sulphate, urethane from Sigma Chemical (Deisenhofen, Germany), N-2-hydroxyethylpiperazine- $\mathrm{N}^{\prime}$-2-ethanesulphonic acid (HEPES), bovine serum albumin (fraction V) from E Merck (Darmstadt, Germany), collagenase from Bayer Diagnostic (München, Germany), minimal Eagle's amino acid supplement from Gibco/BRL (Life Technologie, Eggenstein, Germany), rat galanin from Peninsula Laboratories (Heidelberg, Germany), and [methyl- ${ }^{3} \mathrm{H}$ ] choline chloride from Amersham (Braunschweig, Germany).

\section{METHODS}

\section{In vivo pancreatic secretion studies}

Male starved Sprague-Dawley rats (Zentralinstitut für Versuchstierzucht, Hannover, Germany), weighing between 200-250 g, were anaesthetised with urethane $(1.3 \mathrm{~g} / \mathrm{kg}$ body weight). Body temperature was maintained at $38^{\circ} \mathrm{C}$ with a heating pad. The pancreas was exposed through a midline abdominal incision and the common bile pancreatic duct was cannulated at the sphincter of oddi with a tapered polyethylene tip attached to silastic tubing. A second cannula was placed into the duodenum, slightly above the sphincter for continuous infusion of a trypsin bile acid solution ( $2 \mathrm{mg}$ trypsin, dissolved in $50 \mathrm{mmol} / 1 \mathrm{NaHCO}_{3}, 78 \mu \mathrm{mol} / \mathrm{l}$ sodium taurocholate, rate of infusion $1 \mathrm{ml} / \mathrm{h}$ ). This amount was sufficient to suppress CCK release. ${ }^{17}$ For intravenous infusions a cannula was inserted into the external jugular vein and the incisions covered with a moist gauze.

The diverted bile pancreatic juice was collected in small vials for 15 minute periods, the volume determined, and amylase measured using an autoanalyser (Eppendorf ACP 5040, Hamburg, Germany) according to the method of KruseJarres et $a .^{18}$ After a two hour basal period, atropine $(150 \mu \mathrm{g} / \mathrm{kg} / \mathrm{h})$ or galanin $(10 \mathrm{nmol} / \mathrm{kg} / \mathrm{h})$ was infused intravenously for the remainder of the experiment; control rats received saline. ${ }^{12}$ Thirty minutes after the start of galanin infusion, rats were pretreated with 3-0-methylglucopyranose $(500 \mathrm{mg} / \mathrm{kg} / \mathrm{h})$ for 30 minutes and stimulated with a bolus injection of 2-deoxyglucose (2-DG; $75 \mathrm{mg}$ / $\mathrm{kg}){ }^{19}$ 2-DG stimulates pancreatic secretion by cholinergic central stimulation caused by cytoglucopoenia in the nuclei of the solitary tract. ${ }^{20} 3-0$ methylglucopyranose in addition to 2-DG is thought to aggravate the central cytoglucopoenia. ${ }^{19}$ After the bolus injection of 2-DG pancreatic secretion was measured for additional 120 minutes. Results were expressed as a percentage of basal amylase output.

\section{Isolated pancreatic acini studies}

Isolated rat pancreatic acini were prepared by collagenase digestion, as described previously, to test if galanin directly affects CCK or carbachol stimulated amylase release. ${ }^{21}$ Briefly, pancreatic tissue was incubated in $10 \mathrm{mM}$ HEPES buffered Ringer solution (HR) containing $100 \mathrm{U} / \mathrm{ml}$ collagenase, $6 \mathrm{mM}$ glucose, $0.5 \%$ bovine serum albumin, $0 \cdot 1 \%$ soybean trypsin inhibitor, and Eagle's minimum amino acid supplement; the digestion buffer was additionally injected into the pancreatic interstitium to permit better digestion of tissue. After 30 minutes' incubation at $37^{\circ} \mathrm{C}$ under $\mathrm{O}_{2}$ saturation in a shaking water bath, acini were dispersed with mild shearing forces, passed through a double filter gauze, and purified by sedimentation in $4 \%$ bovine serum albumin. Acini were washed three times in HR and added in aliquots to prepared vials containing CCK 8 or carbachol in the presence or absence of galanin $(1 \mu \mathrm{M})$. The vials were incubated under $\mathrm{O}_{2}$ saturation at $37^{\circ} \mathrm{C}$ in a shaking water bath for 30 minutes. The reaction was stopped by placing the vials on ice and separating the cells by centrifugation. Amylase released into the medium and total acinar amylase content were measured. All experiments were done in triplicate and amylase released was expressed as a percentage of initial total amylase content.

\section{Pancreatic lobule studies}

Pancreatic lobules containing postganglionic neural elements and islets were prepared by the method of Scheele and Palade. ${ }^{22}$ Briefly, the pancreas was removed and HR buffer solution injected into the interstitium. Lobules were excised with forceps and scissors. The lobules were washed and transferred into baskets with mesh bottoms allowing the buffer to drain but retain the lobules. The baskets were placed into temperature controlled chambers at $37^{\circ} \mathrm{C}$ under a constant drip $(0.5 \mathrm{ml} / \mathrm{min})$ of HR buffer. The superfusion medium was collected under the basket in small vials. After a 45 minute adjustment period in the chambers five 4 minute basal collections were taken and the lobules were stimulated with the sodium channel activator veratridine $(10 \mu \mathrm{M}-500 \mu \mathrm{M})$ for eight minutes. ${ }^{23}$ Veratridine has no effect on pancreatic acini $^{24}$; it is known to depolarise existing cells by blocking the inactivation of $\mathrm{Na}^{+}$channels. ${ }^{25}$ Each stimulation was followed by eight 4 minute collection periods. In the different treatment groups atropine $(1 \mu \mathrm{M})$ or tetrodotoxin $(1 \mu \mathrm{M})$, a specific sodium channel blocker, or galanin (1 $\mu \mathrm{M}$ ) was already added individually to the superfusion buffer 20 minutes before and throughout the stimulation period. At the end of the experiment, the lobules were homogenised with a Wheaton-Dounce glass-glass homogeniser. Amylase content of the homogenates and the superfusion medium was determined and results are expressed as a percentage of basal fractional release. Baseline secretion is expressed as $100 \%$.

Acetylcholine release studies

Acetylcholine release was measured by the 


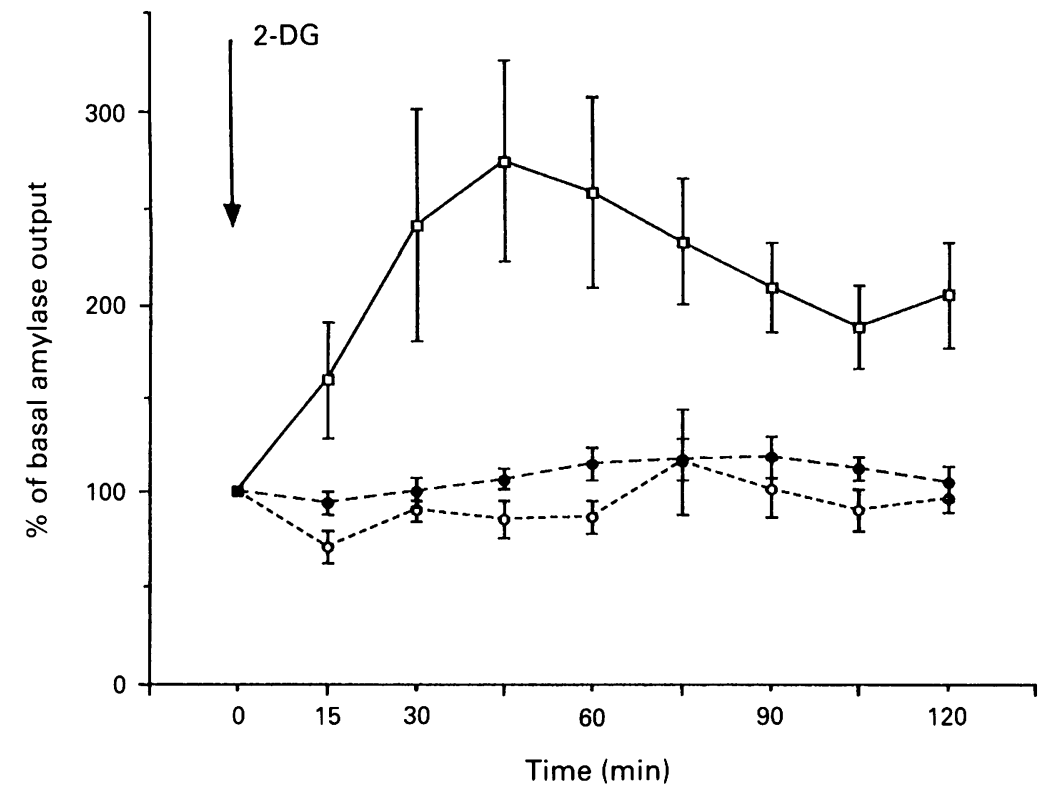

Figure 1: Effect of atropine and galanin on 2-deoxyglucose (2-DG) stimulated amylase output in anaesthetised rats. After a two hour basal period atropine $(150 \mu \mathrm{g} / \mathrm{kg} / \mathrm{h})$ or galanin $(10$ $n \mathrm{~mol} / \mathrm{kg} / \mathrm{h}$ ) were infused throughout the remainder of the experiment. Rats were pretreated with 3-0-methylglucopyranose for 30 minutes before the bolus injection of 2-DG $(75 \mathrm{mg} / \mathrm{kg})$ 2-DG ( $\square$ ), 2-DG+atropine (o), 2-DG+ galanin (O). Two way analysis of variance with repeated measures showed a significant inhibitory effect of atropine and galanin over time $(F=8 \cdot 7 ; p<0 \cdot 05 ; d f 1 / 18)$; values are means of eight experiments.
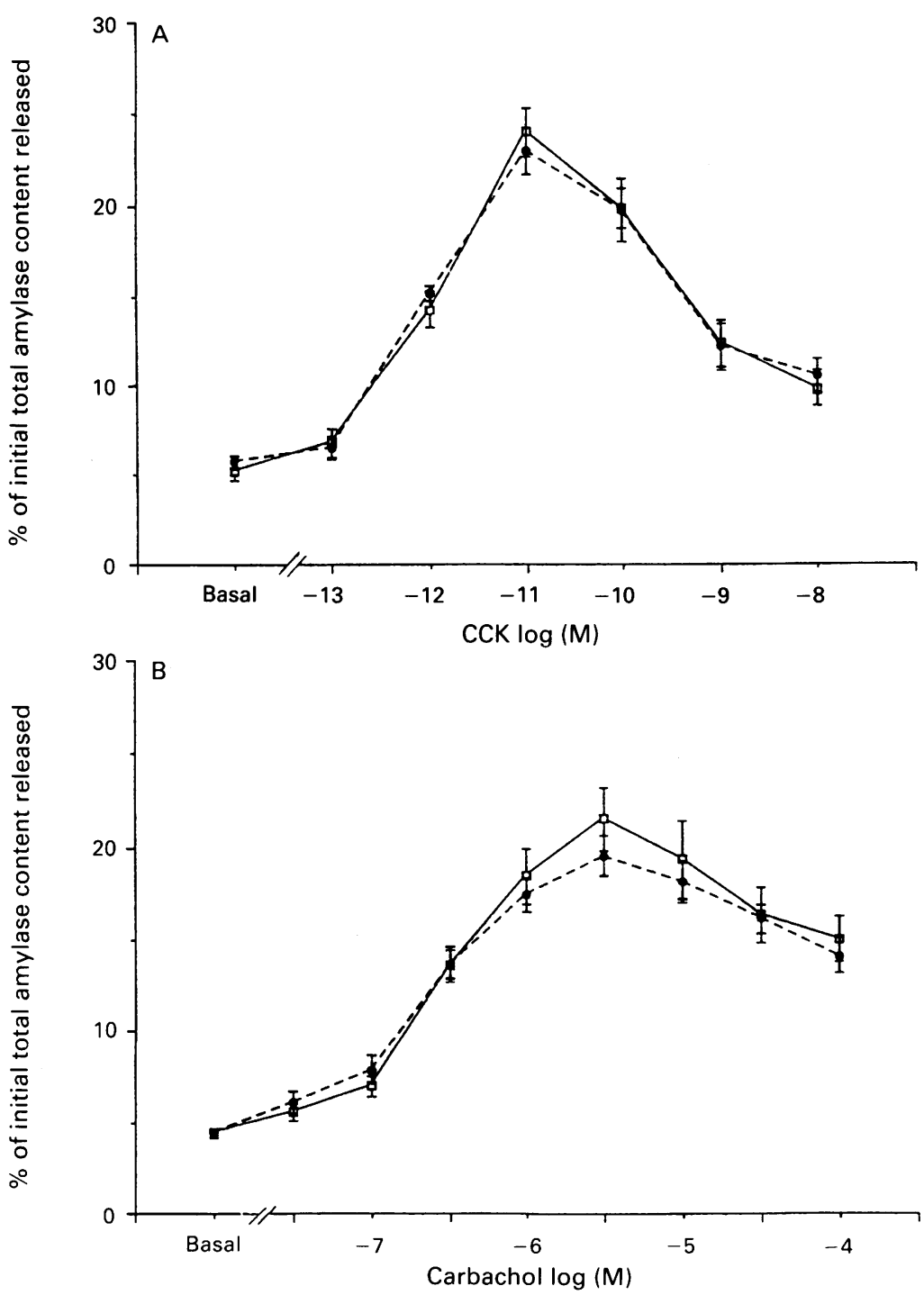

Figure 2: Effect of galanin on cholecystokinin $8(C C K 8)(A)$ and carbachol $(B)$ stimulated amylase release from isolated pancieatic acini. Control acini $(\square)$, acini treated with galanin $(1 \mu M)(0)$. Values are means of seven experiments. method described by $\mathrm{Wu}$ et $a l{ }^{26}$ Pancreatic lobules were depleted of endogenous acetylcholine by electrical field stimulation. Platinum wires were attached to the bottom of a basket, which was placed into a heating chamber under a constant drip. Pulses of $1 \mathrm{~ms}$ duration at $4 \mathrm{~Hz}$ at 40 volts were given for 15 minutes. The lobules were incubated with $0 \cdot 2 \mu \mathrm{M}$ [methyl- ${ }^{3} \mathrm{H}$ ] choline chloride in HR buffer containing $50 \mu \mathrm{M}$ physostigmine, a cholinesterase inhibitor, at $37^{\circ} \mathrm{C}$ for 45 minutes in a shaking incubator under $\mathrm{O}_{2}$ saturation. Afterwards the lobules were washed six times for $\mathbf{1 0}$ minutes and transferred into the baskets. Hemicholinium (10 $\mu \mathrm{M})$ was added to the buffer to prevent released acetylcholine being taken up again. The same perfusion system and experimental design as described above was used in the pancreatic lobule studies. Instead of amylase measurement $1 \mathrm{ml}$ of collected superfusion buffer was added to $9 \mathrm{ml}$ of scintillation fluid (Quickzint 2000; Zinser Analytic, Germany). The lobules were solubilised overnight in $10 \%$ sodium dodecyl sulfate. Radioactivity was counted in a Beckman LS-7800 scintillation counter. Counts were expressed as a percentage of basal fractional release. Baseline secretion is expressed as $100 \%$. Veratridine evoked $\left[{ }^{3} \mathrm{H}\right]$ efflux has been called $\left[{ }^{3} \mathrm{H}\right]$-acetylcholine, because earlier studies showed that virtually all the veratridine evoked release of $\left[{ }^{3} \mathrm{H}\right]$ activity from intrapancreatic cholinergic ganglia represents $\left[{ }^{3} \mathrm{H}\right]$-acetylcholine. ${ }^{27} 28$

\section{STATISTICS}

Results are expressed as mean (SEM). Data were analysed using analysis of variance with the method of Dunn for multiple contrasts or Student's $t$ test where appropriate. Statistical significance was set at $\mathrm{p}<0.05$.

\section{Results}

IN VIVO STUDIES

Basal amylase output was monitored two hours before the start of galanin to ensure a complete suppression of the negative feedback mechanism. ${ }^{17}$ Basal amylase output averaged 1544 U/h. Pretreatment with 3-0-methylglucopyranose $(500 \mathrm{mg} / \mathrm{kg} / \mathrm{h})$ before the bolus injection of 2-DG did not stimulate amylase output (data not shown). Bolus injection of 2-DG (75 $\mathrm{mg} / \mathrm{kg}$ ) raised amylase output by $274(19) \%$ within 45 minutes (Fig 1). Atropine $(150 \mu \mathrm{g} / \mathrm{kg} / \mathrm{h})$ blocked the stimulatory effect of 2-DG completely proving that 2-DG acts by cholinergic pathways to stimulate pancreatic enzyme secretion (Fig 1). Also galanin (10 nmol/ $\mathrm{kg} / \mathrm{h}$ ) completely inhibited 2-DG-stimulated amylase output suggesting that galanin might affect cholinergic transmission (Fig 1).

\section{IN VITRO STUDIES}

\section{Isolated pancreatic acini studies}

In isolated pancreatic acini stimulation with various concentrations of CCK8 and carbachol stimulated amylase release in the typical biphasic 


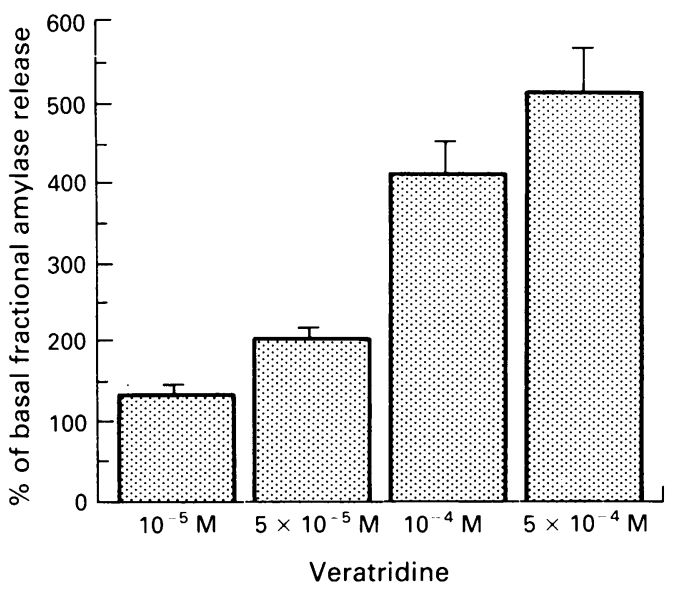

Figure 3: Amylase release from pancreatic lobules containing neural elements in response to veratridine, a sodium channel activator. Values are means of at least six experiments.

fashion with an optimal secretion at $10 \mathrm{pM}$ and 5 $\mu \mathrm{M}$, respectively (Fig 2). Galanin at $1 \mu \mathrm{M}$ did not change the amylase response to $\mathrm{CCK} 8$ or carbachol showing that galanin has no direct effect on the pancreatic acini to inhibit amylase secretion and that the inhibitory effect of galanin seen in vivo has to be indirect (Fig 2). Lower doses of galanin were without any effect as well.

\section{Pancreatic lobule studies}

In pancreatic lobules the sodium channel activator veratridine depolarises these neurons causing a dose dependent amylase release into the superfusion buffer (Fig 3). The sodium channel activator veratridine $(100 \mu \mathrm{M})$ caused a $412(10) \%$ stimulation of basal amylase release. Tetrodotoxin (1 $\mu \mathrm{M})$, a specific sodium channel blocker, abolished amylase secretion stimulated by the highest dose of veratridine used (Fig 4). Atropine $(1 \mu \mathrm{M})$ also blocked the effect of veratridine showing that veratridine stimulated amylase release is mediated by a cholinergic pathway. Addition of galanin to the superfusion buffer for 20 minutes caused a $50 \%$ inhibition of veratridine $(100 \mu \mathrm{M})$ stimulated amylase release providing further evidence that galanin inhibits cholinergic transmission (Fig 5).

To prove this hypothesis, we preincubated

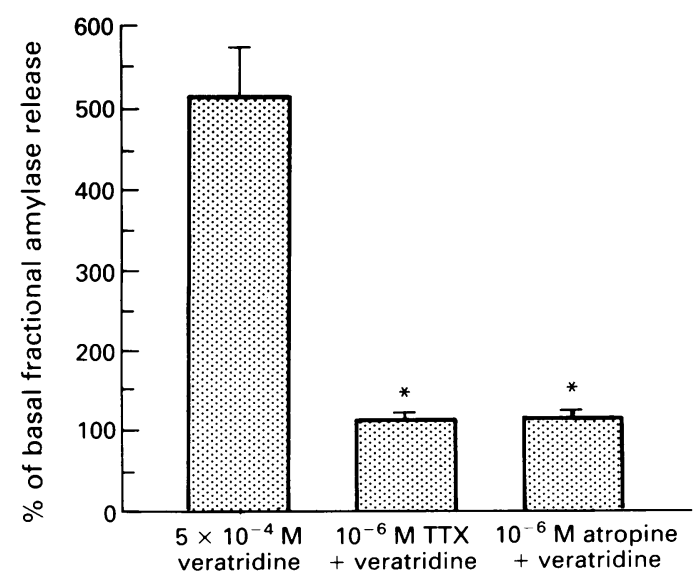

Figure 4: Effect of atropine or tetrodotoxin (TTX) on veratridine stimulated amylase release from pancreatic
lobules. Values are means of six experiments. ${ }^{\star} p<0.05$

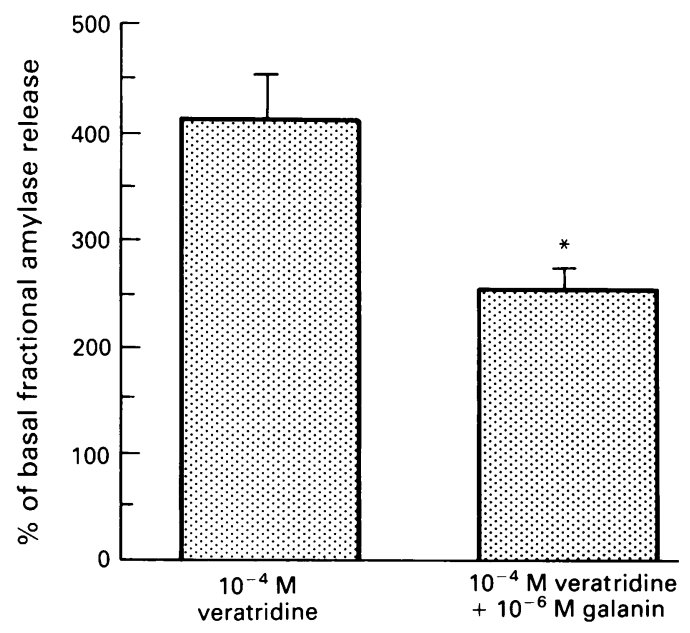

Figure 5: Effect of galanin on veratridine stimulated amylase release from pancreatic lobules. Values are means of 11 experiments. ${ }^{\star} p<0.05$.

pancreatic lobules with [methyl- ${ }^{3} \mathrm{H}$ ] choline chloride for 45 minutes, which is synthesised to $\left[{ }^{3} \mathrm{H}\right]$-acetylcholine and measured release of radioactivity from the lobules in response to veratridine. Veratridine $(500 \mu \mathrm{M})$ stimulated $\left[{ }^{3} \mathrm{H}\right]$-acetylcholine release by 177 (6)\% (Fig 6). Galanin treatment inhibited this stimulation to 114 (3)\% providing direct evidence that galanin inhibits pancreatic secretion by an inhibition of cholinergic transmission (Fig 6).

\section{Discussion}

Galanin completely inhibited 2-DG stimulated amylase release in anaesthetised rats - a stimulus that is known to act by cholinergic pathways. ${ }^{190}$ Yagci et al found that galanin potently inhibited bombesin, secretin, and cholecystokinin stimulated pancreatic protein and amylase secretion in the anaesthetised rat. ${ }^{12}$ According to the study from Yagci et al we used a maximal dose of galanin to test the effect on cholinergically stimulated amylase secretion and did not perform additional experiments with lower concentrations, because our aim was to further elucidate the inhibitory mechanism.

In isolated pancreatic acini galanin failed to

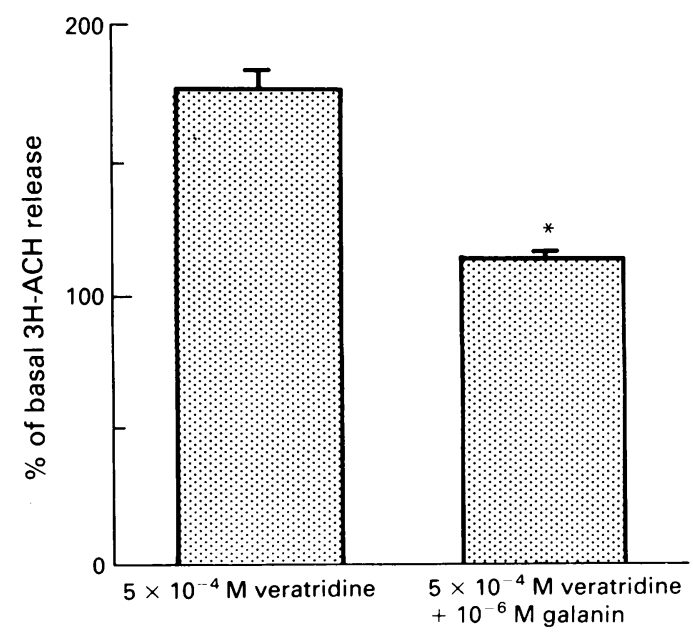

Figure 6: Effect of galanin on veratridine stimulated ${ }^{~} \mathrm{H}$ acetylcholine $\left({ }^{i} \mathrm{H}-\mathrm{ACH}\right)$ release from pancreatic lobules. Values are means of nine experiments. ${ }^{\star} p<0 \cdot 05$. 
have any inhibitory action on CCK 8 or carbachol stimulated amylase release. By contrast with our findings, Ahren et al reported a weak, but significant, inhibitory action on CCK8 and carbachol stimulated amylase release in isolated rat pancreatic acini. ${ }^{16}$ They used different concentrations of galanin (100 pM-100 $\mathrm{nM}$ ) on amylase secretion stimulated by a supramaximal dose of CCK8 (10 nM) and a submaximal dose of carbachol $(10 \mu \mathrm{M})$. At $10 \mathrm{nM}$ CCK they saw a $9 \cdot 7$ $(0.6) \%$ stimulation of total amylase release. Addition of galanin (100 $\mathrm{nM}$ ) reduced amylase secretion to $8 \%$ only. Carbachol stimulated amylase release by $13.5 \%$; addition of galanin (1 $\mathrm{nM}$ ) reduced stimulation to $11 \cdot 25 \%$. The inhibition by galanin seems to be rather weak. To see a direct effect of galanin, we tested the highest concentration of galanin $(1 \mu \mathrm{M})$ on various doses of CCK8 and carbachol. Our acini were far more responsive to CCK8 and carbachol with the maximal secretion of $24(1 \cdot 3) \%$ at $(10 \mathrm{pM})$ and $21 \cdot 6(1 \cdot 7) \%$ at $(5 \mu \mathrm{M})$, respectively (see Fig 2$)$. Interestingly, in the study reported by Ahren et al higher doses of galanin (for example, $100 \mathrm{nM} v 10$ or $1 \mathrm{nM}$ ) did not inhibit carbachol stimulated amylase release. To propose a direct effect of galanin on pancreatic acini, specific receptors must exist on the acinar cell as they have been found on hamster $B$ cells and the insulinoma cell line Rin m 5F. ${ }^{29}{ }^{30}$ Higher concentration of galanin should lead to a higher occupancy of possible galanin receptors on the acinar cells and therefore result in a greater inhibition of amylase secretion. Overall, the weak inhibitory effect of galanin on pancreatic acini reported by Ahren et al cannot account for the complete inhibition of 2-DG stimulated amylase secretion seen in vivo. It remains unclear if the reduced responsiveness of their acini accounts for the different findings in isolated pancreatic acini.

Because there was not a direct effect of galanin on pancreatic acini in our preparation we investigated possible indirect mechanisms. Veratridine dose dependently stimulated amylase release in pancreatic lobules by depolarising neural elements in the lobules, which was significantly inhibited by galanin. Proof that galanin indeed inhibits cholinergic transmission from presynaptic cholinergic neurons was provided by the $\left[{ }^{3} \mathrm{H}\right]$-acetylcholine study. Galanin significantly inhibited $\left[{ }^{3} \mathrm{H}\right]$-acetylcholine release. These results provide direct evidence that galanin inhibits pancreatic enzyme secretion by inhibiting presynaptic cholinergic transmission.

Because galanin did not completely block amylase release, it might be possible that additional inhibitory mechanisms are responsible for the full inhibitory action of this peptide. The secretion of the islet hormones somatostatin, glucagon, and pancreatic polypeptide - all known inhibitors of exocrine pancreatic secretion - are inhibited rather than stimulated by galanin. ${ }^{4}$ On the other hand, insulin secretion is inhibited as well. A recent study showed that anti-insulin serum could block the postprandial exocrine pancreatic secretion, ${ }^{31}$ yet the mechanism of insulin's action on pancreatic secretion is not known. A reduced insulin secretion could account in part for the diminished exocrine secretion in vivo, although the effects of hyper- glycaemia on pancreatic secretion are contradictory. ${ }^{32} 33$

The results of this study fit into the general concept of pancreatic enzyme regulation. The importance of the cholinergic nervous system during the intestinal phase of digestion has been well reported. ${ }^{34}{ }^{35}$ Adler et al showed in humans a complete blockade of meal stimulated pancreatic enzyme secretion by atropine, while the potent CCK receptor antagonist loxiglumide caused only a $60 \%$ inhibition. Inhibitory peptides like galanin, pancreatic polypeptide, pancreastatin, peptide YY, and neuropeptide Y modulate stimulated pancreatic secretion by reducing acetylcholine release..$^{27} 283637$ The results of this study show that galanin is a functional member of this family. Although the exact significance of galanin in the regulation of pancreatic enzyme secretion is currently unknown, the new powerful receptor antagonist $M-15$ will provide us with the tool to further elucidate the complex regulation of pancreatic enzyme secretion. ${ }^{38}$

In summary, this study has shown that galanin is a powerful inhibitor of pancreatic enzyme secretion. Galanin elicits its inhibitory action indirectly, partly by inhibition of acetylcholine release from intrapancreatic neurons.

This paper is dedicated to Professor Dr med G Paumgartner, Department of Medicine II, Klinikum Grosshadern, Ludwig Maximilian-University, Munich, Germany, on the occasion of his 60th birthday.

This investigation was supported in part by the Deutsche Forschungsgemeinschaft (He 1965/1-1). The study was presented in part at the 93rd Annual Meeting of the American Gastroenterology Association, 1992, in San Francisco, Ca. The authors thank Cornelia Wilgus for excellent technical assistance.

1 Tatemoto K, Rökaeus A, Jörnvall H, McDonald TJ, Mutt V. Galanin. A novel biologically active peptide from porcine intestine. FEBS Lett 1983;164: 124-8.

2 Bauer FE. Galanin: Ein neues biologisch aktives gastrointestinales Neuropeptid. Z Gastroenterol 1990; 28: 160-9.

3 Rattan S. Role of galanin in the gut. Gastroenterology 1991; 100: 1762-8.

4 Ahren B, Lindskog S. Galanin and the regulation of islet hormone secretion. Int F Pancreatol 1992; 11: 147-60

5 Crawley JN. Coexistence of neuropeptides and "classical" neurotransmitters: Functional interactions between galanin and acetylcholine. Ann NY Acad Sci 1990; 574: 233-45.

6 Dunning BE, Ahren B, Veith RC, Böttcher G, Sundler F, Taborsky GJ Jr. Galanin: a novel pancreatic neuropeptide. Am F Physiol 1986; 251: E127-33.

7 Messel T, Harling H, Böttcher G, Johnsen AH, Holst JJ. Galanin in the porcine pancreas. Regul Pept 1990; 28 161-76.

8 Lindskog S, Ahren B, Dunning BE, Sundler F. Galaninimmunoreactive nerves in the mouse and rat pancreas. immunoreactive nerves in the
Cell Tissue Res 1991; 264: 363-8.

9 Shimosegawa T, Moriizumi S, Koizumi M, Kashimura J, Yanaihara N, Toyota T. Immunohistochemical demonstration of galaninlike immunoreactive nerves in the human pancreas. Gastroenterology 1992; 102: 263-71.

10 Dunning BE, Taborsky GJ. Galanin release during pancreatic nerve stimulation is sufficient to influence islet function. Am F Physiol 1989; 256: E191-8.

11 Bauer EF, Zintel A, Kenny MJ, Calder D, Ghatei MA, Bloom SR. Inhibitory effect of galanin on postprandial gastrointestinal motility and gut hormone release in humans. Gastroenterology 1989; 97: 260-4.

12 Yagci RV, Altekin N, Zacharia S, Coy DH, Ertan A, Rossowski WJ. Galanin inhibits pancreatic amylase secretion in pentobarbital-anaesthetized rats. Regul Pept 1991; tion in pent $275-82$.

13 Yau WM, Dorsett JA, Youther ML. Evidence for galanin as an inhibitory neuropeptide on myenteric cholinergic neurons in the guinea pig small intestine. Neurosci Lett 1986; 72: 305-8.

14 Tamura K, Palmer JM, Wood JD. Galanin suppresses nicotinic synaptic transmission in the myenteric plexus of guinea pig small intestine. Eur F Pharmacol 1987; 136: 445-6.

15 Fisone G, Wu FC, Consolo S, Nordström Ö, Brynne N, Bartfai T, et al. Galanin inhibits acetylcholine release in the ventral hippocampus of the rat: Histochemical, autoradiographic, in vivo and in vitro studies. Proc Natl Acad Sci USA 1987; 84: 7339-43.

16 Ahren B,Andren-Sandberg A, Nilsson A. Galanin inhibits amylase secretion from isolated rat pancreatic acini. Pancreas 1988; 3: 559-62.

17 Fölsch UR, Cantor P, Wilms HM, Schafmayer A, Becker HD, Creutzfeldt W. Role of cholecystokinin in the negative 
feedback control of pancreatic secretion in conscious rats. Gastroenterology 1987; 92: 449-58.

18 Kruse-Jarres JD, Kaiser C, Hafkenscheid JCM, Hohenwallner W, Stein W, Bohner J, et al. Evaluation of a new a-amylase assay using 4,6-ethylidene-( $\left.G_{7}\right)-1-4$ nitrophenyl- $\left(\mathrm{G}_{1}\right)-\mathrm{a}-\mathrm{D}$-maltoheptaoside as substrate. $\mathcal{F}$ Clin Chem Clin Biochem 1989; 27: 103-13.

19 Hirschowitz B, Sachs G. Vagal gastric secretory stimulation by 2-deoxy-D-glucose. Am f Physiol 1965; 209: 452-60.

20 Kadekaro M, Timo-Iaria C, Vicentini M de L. Gastric secretion provoked by functional cytoglucopoenia in the nuclei of the solitary tract in the cat. 7 Physiol 1980; 299. $397-407$.

21 Williams JA, Korc M, Dormer RL. Action of secretagogues on new preparation of functionally intact, isolated pancreatic acini. Am F Physiol 1978; 235: E517-24.

22 Scheele GA, Palade GE. Studies on the guinea pig pancreas. Parallel discharge of exocrine enzyme activities. F Biol Chem 1975; 250: 2660-70.

23 Horneriäger $\mathbf{P}$, Reiter $M$. The relation between the effects of veratridine on action potential and contraction in mammalian ventricular myocardium

24 Gallagher S, Sankaran H, Williams JA. Mechanism of scorpion toxin induced enzyme secretion in rat pancreas. Gastroenterology 1981; 80: 970-3.

25 Ohta M, Narahashi T, Keeler RF. Effect of veratrum alkaloids on membrane potential and conductance of squid and crayfish giant axons. $f$ Pharmacol Exp Ther 1973; 184: 143-54.

26 Wu ZC, Kisslinger SD, Gaginella TS. Functional evidence for the presence of cholinergic nerve endings in the colonic

27 Jung G, Louie DS, Owyang C. Pancreatic polypeptide inhibits pancreatic enzyme secretion via a cholinergic pathway. pancreatic enzyme secretion via
Am $\mathcal{F}$ Physiol 1987; 257: G706-10.

28 Herzig KH, Louie DS, Tatemoto K, Owyang C. Pancreastati inhibits pancreatic enzyme secretion by presynaptic modula- tion of acetylcholine release. Am $\mathcal{F}$ Physiol 1992; 262: G113-7.

29 Amiranoff B, Servin Al, Rouyer-Fessard C, Courineau A Tatemoto $\mathrm{K}$, Laburthe $M$. Galanin receptors in a hamster pancreatic $B$-cell tumor: Identification and molecular characterization. Endocrinology $1987 ; 121: 284-9$.

30 Amiranoff B, Lorinet AM, Laburthe M. Galanin receptor in the rat pancreatic $B$ cell line. Molecular characterization by chemical cross-linking. F Biol Chem 1989; 264: 20714-7.

31 Lee KY, Zhou L, Ren XS, Chang TM, Chey WY. An important role of endogenous insulin on exocrine pancreatic secretion in rats. Am $\mathcal{F}$ Physiol 1990; 258: G268-74.

32 MacGregor IL, Deveney C, Way LW, Meyer JH. The effect of acute hyperglycemia on meal-stimulated gastric, biliary and pancreatic secre 1976; 70: 197-202.

33 Bruzzone R, Trimble ER, Gjinovci A, Renold AE. Glucoseinsulin interactions on exocrine secretion from the perfused insulin interactions on exocrine secretion from the

34 Adler G, Reinshagen M, Koop I, Göke B, Schafmayer A Rovati LC, et al. Differential effects of atropine and a cholecystokinin receptor antagonist on pancreatic secretion. Gastroenterology 1989; 96: 1158-64.

35 Adler G, Beglinger C, Braun U, Reinshagen M, Koop I Schafmayer A, et al. Interaction of the cholinergic system and cholecystokinin in the regulation of endogenous and exogenous stimulation of pancreatic secretion in humans. Gastroenterology 1991; 100: 537-43.

36 Putnam WS, Liddle RA, Williams JA. Inhibitory regulation of rat exocrine pancreas by peptide YY and pancreatic polypeptide. Am 7 Physiol 1989; 256: G698-703.

37 Mulholland MW, Lally K, Taborsky GJ Jr. Inhibition of rat pancreatic exocrine secretion by neuropeptide $Y$ : Studies in pancreatic exocrine secretion by neuropeptide
vivo and in vitro. Pancreas $1991 ; 6: 433-40$.

38 Bartfai T, Bedecs K , Land T, Langel UU, Bertorelli R, Girott $P$, et al. M-15: High-affinity chimeric peptide that blocks the neuronal actions of galanin in the hippocampus, locus coeruleus, and spinal cord. Proc Natl Acad Sci USA 1991 88: $10961-5$ 